\title{
Automated Method for Delineating Watershed, Drainage Pattern and Calculation of Flow Accumulation in Punjab Province using Digital Elevation Model
}

\author{
Umair bin Zamir* and Jamil Hassan Kazmi \\ Department of Geography, University of Karachi, Karachi-75270, Pakistan
}

(receivd November 26, 2013; revised June 1, 2014; accepted June 25, 2014)

\begin{abstract}
Delineation of the watershed and drainage is among the prior requirement of any organised hydrological study. Delineating watershed is important for elucidating the geo-hydrological conditions of any geographical space. This study aims to explore the vitality of Digital Elevation Model (DEM) data in calculating the flow accumulation, flow length, drainage pattern and watershed basin delineation of Punjab as well as elevational profiling district wise and delineating the catchment density. The potential hydrological system developed is based on 1 arc second Aster GDEM data. Depression less DEM is developed by filling process. Furthermore flow accumulation, drainage pattern and watershed is demarcated on the basis of derived stream channels. This study presents the effectiveness of DEM data for hydrological studies and introduces a better method of water management in Punjab province of Pakistan.
\end{abstract}

Keywords: DEM, watershed, flow accumulation, drainage pattern

\section{Introduction}

The advent of satellite technology and access to a variety of remote sensing and GIS data types increases the

\section{PAKISTAN}

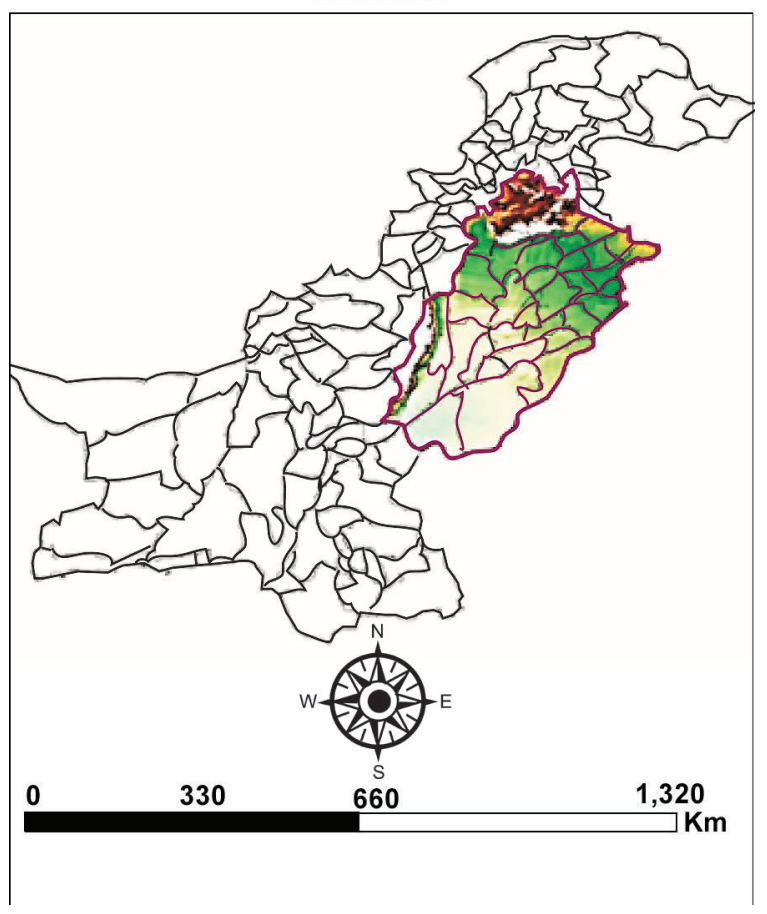

Fig. 1. Study area (Punjab province). prospects of understanding the terrain of geographical space with remarkable accuracy. GIS and remote sensing offers the combination of apparatus to speed up the decision and helps in enumerating more precise results.

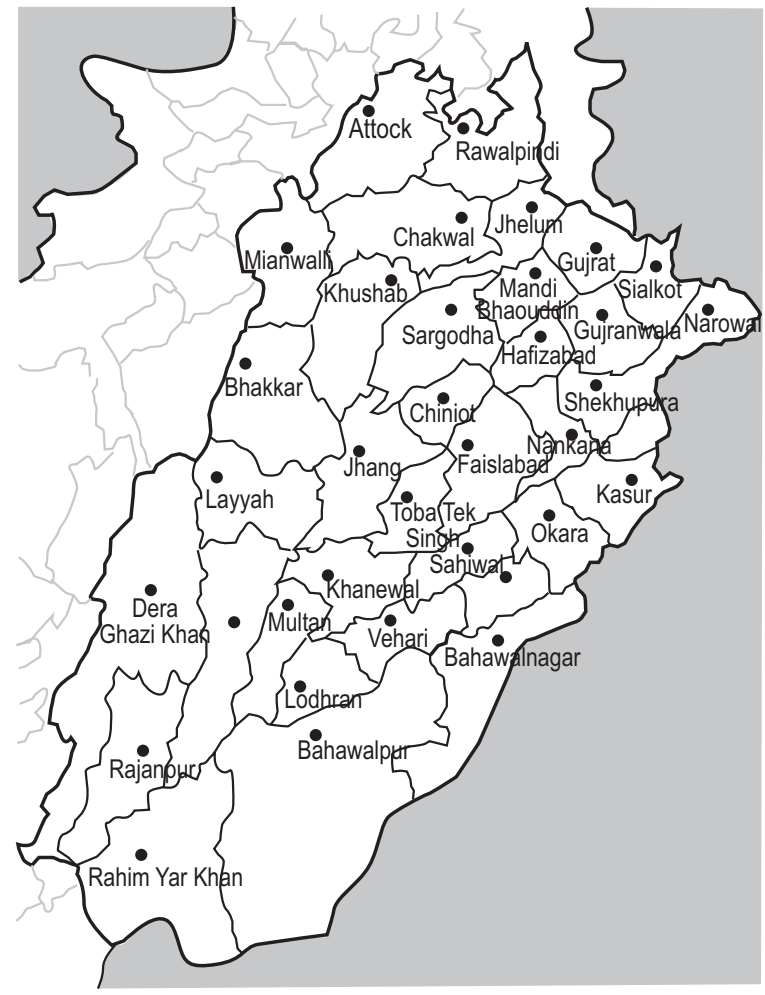

*Author for correspondence; E-mail: binzamir@hotmail.com 
Hydrological risks and jeopardies can easily be cut and dried and tactics formulated to alleviate the loss and increases the decision making abilities. Geographic Infor-mation System (GIS) and Remote Sensing (RS) is an authoritative combination of technology, which is helpful in hydrological modeling, monitoring and mitigation. By using the Digital Elevation Model (DEM) automated and accurate watershed delineation and development of drainage network is possible, which is comparatively less time consuming, more accurate and provide easily calculable measurements than traditional manual techniques. GIS and RS have the aptitude to perform watershed management and help in developing high accuracy oriented hydrological mapping which promotes the Spatial Decision Support System (SDSS).

\section{Materials and Methods}

Study area. Various techniques are used for getting the desired objectives; methodological framework is classified into six stages (Fig. 2).

Data acquisition. The major data was obtained on request, from the United States Geological Survey (USGS). Most of the files were downloaded from there by assigning the Keyhole Markup Language (KML), file for the study area and by uploading it. Digital Elevation Model (DEM) raster scenes of the study area were selected and downloaded.

DEM reconditioning. DEM data obtained is not perfect for using until it is reconditioned. Sinks and Peaks (Fig. 3) are among the common resolution errors, therefore it is required to fill the sinks for proper delineation of watershed and streams. Filling of DEM helps in avoiding

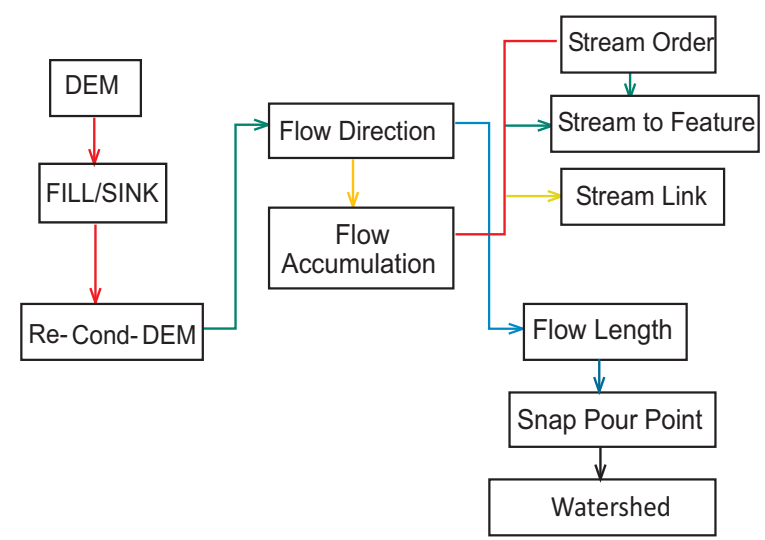

Fig. 2. Methodological framework (steps for delineating watershed). discontinuity of the derived drainage network. The fill function in ArcGIS recapitulates until $\mathrm{Z}$ limits are filled (Tarboton et al., 1991).

Calculating flow direction. Flow direction is calculated by directing steepest lineage obtained from each cell value (Fig. 4). The calculation is made as Change in z-value/distance* 100. All distances calculated are focusing cell centres. In case of cell extent is 1 then the distance between two orthogonal cells is 1, while if two cells flow towards each other are considered as sinks and have ill-defined flow direction (Jenson and Domingue, 1988).

Calculating flow accumulation. Flow accumulation is calculated by using flow accumulation tool in which cell values are designated as weightage flowing into each downslope cell in the output (Fig. 5). Cells of high
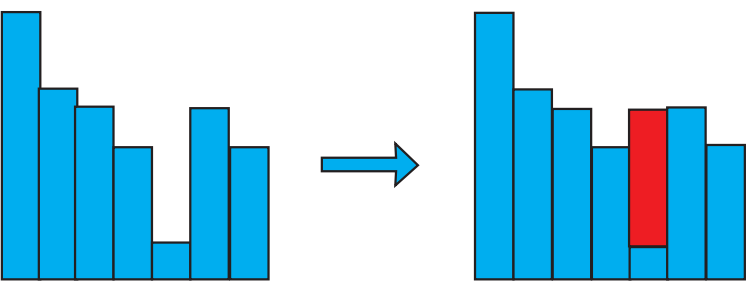

Filled Sinks
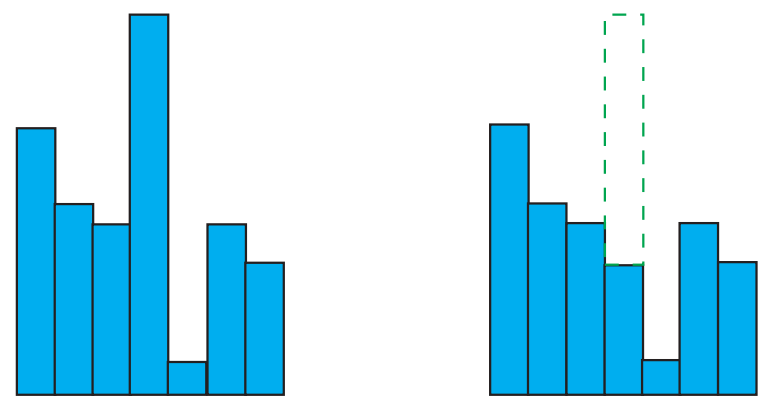

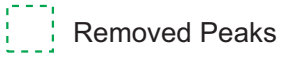

Fig. 3. Profile view of fill.

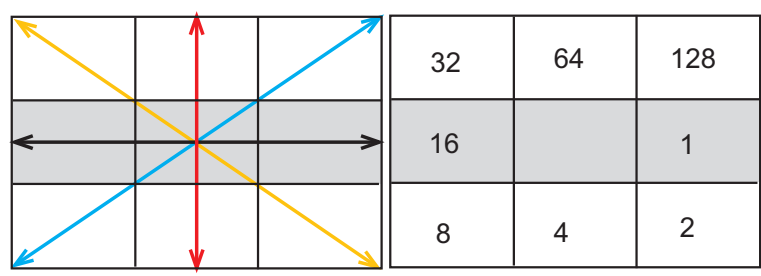

Fig. 4. Flow direction. 
flow accumulation identifying areas of concentrated flow, cells with 0 accumulation values identified as ridges. Extracted flow accumulation used to create a stream network which requires to assign threshold, setnull (flowacc < 100, 1) (Tarboton et al., 1991).

Identifying stream network. The output obtained from flow accumulation was further used for the identification of stream network, by applying the threshold using map

\begin{tabular}{|c|c|c|c|c|c|}
\hline 0 & 0 & 0 & 0 & 0 & 0 \\
\hline 0 & 1 & 1 & 2 & 2 & 0 \\
\hline 0 & 3 & 7 & 5 & 4 & 0 \\
\hline 0 & 0 & 0 & 15 & 0 & 1 \\
\hline 0 & 0 & 0 & 1 & 20 & 0 \\
\hline 0 & 2 & 4 & 8 & 30 & 2 \\
\hline
\end{tabular}

Fig. 5. Flow accumulation grid.

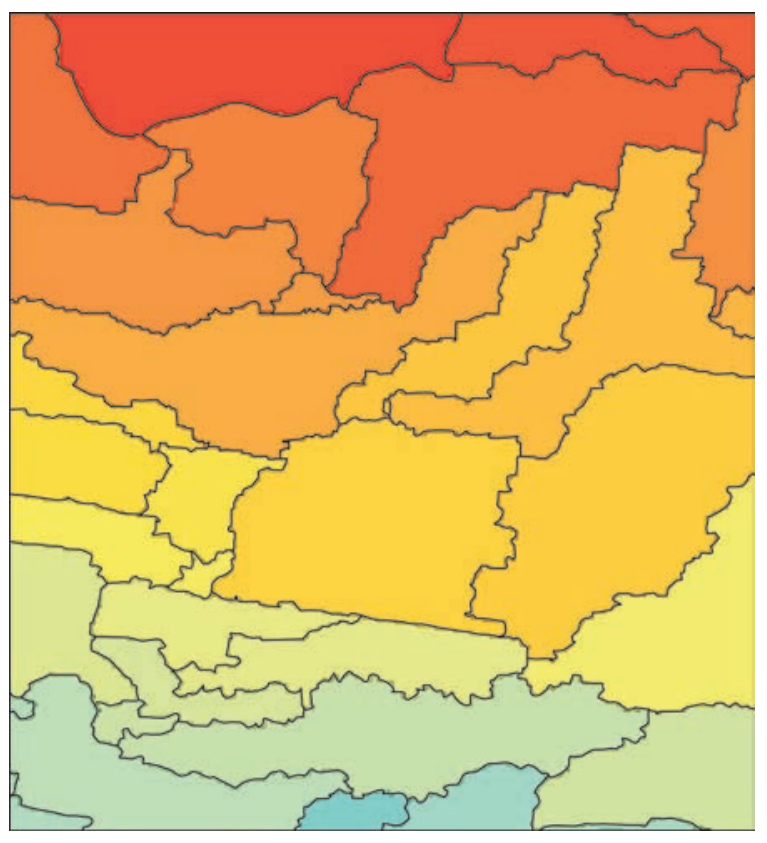

Fig. 6. Watershed. algebra to the flow accumulation raster a stream network is outlined.

Delineating watershed. The final objective of this study is delineating watershed. Watershed is the upslope area which is playing its role in providing flow to given location, this type of zone is also referred as the catchment. For this to achieve flow direction raster is used in ArcGIS watershed function to determine the contributing areas (Fig. 6). In this study, flow accumulation threshold with specific pour point is used to delineate the watershed.

\section{Results and Discussion}

Advancement in Geographical Information System (GIS) and Remote Sensing (RS) in terms of availability of data and the advent of new tools increases the efficiency typically in hydrological studies which lead towards minimizing the expenses of acquisition of data as well as reduces the time and effort in performing the task with accuracy. Combo aid of GIS and RS helps in addressing the water resource issues and helps in investigating and modeling the solution of the issues. From the last two decades information acquisition paradigm rapidly shifted towards digital representations of topography (Martz and Garbrecht, 1992; Moore et al., 1991; Jenson and Domingue, 1988; Mark, 1984). The automated method was applied to the district of Punjab, Pakistan in order to demarcate the watershed, drainage pattern and flow accumulation (Fig. 7). In addition, elevation based characteristics are also extracted district wise (Table 1). By using 1 arc-second Aster GDEM Digital Elevation Model data statistical variational maps are developed representing the different district wise elevation characteristics (Fig. 8). This will be helpful in modeling the different hydrological studies. Furthermore, extracted elevation data is used in order to get the flow direction share district wise (Table 2) which helps in developing the flow accumulation probability plot district wise categorizes the Punjab in low, moderate and high accumulation probability zone (Fig. 9). Muzafargarh, Rajanpur are at high probability of accumulation, and Jhang, Multan, Rahimyarkhan and Bhawalpur are in the moderate accumulation category, while the remaining districts are in the low accumulation zone. Furthermore, the catchment area is delineated (Fig. 10) which is overlaid on the district boundaries of Punjab so that the catchment density district wise is calculated using polygon in polygon analysis (Fig. 11). It represents the east and the 


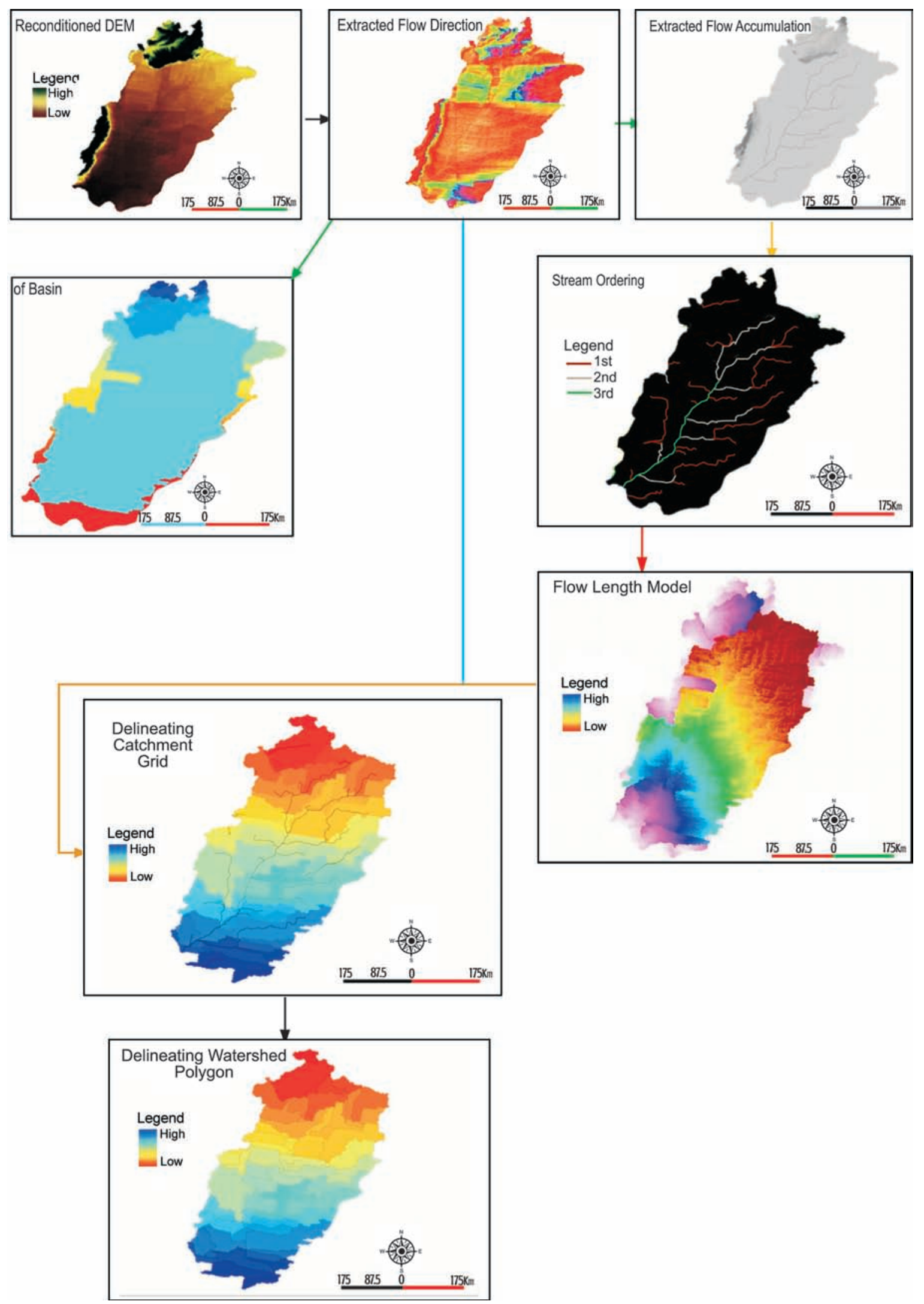

Fig. 7. Delineated results (steps from reconditioning to watershed delineation). 


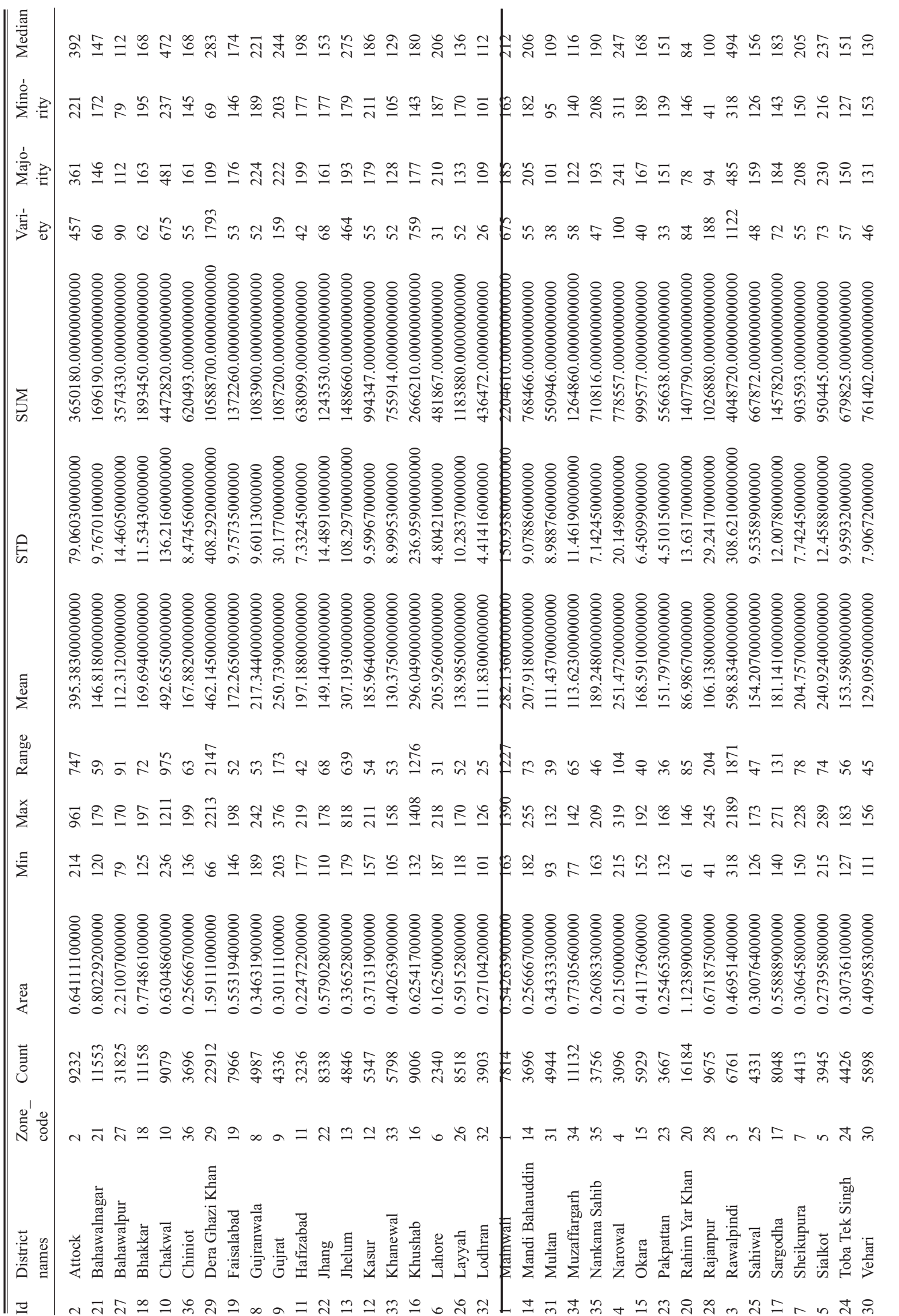



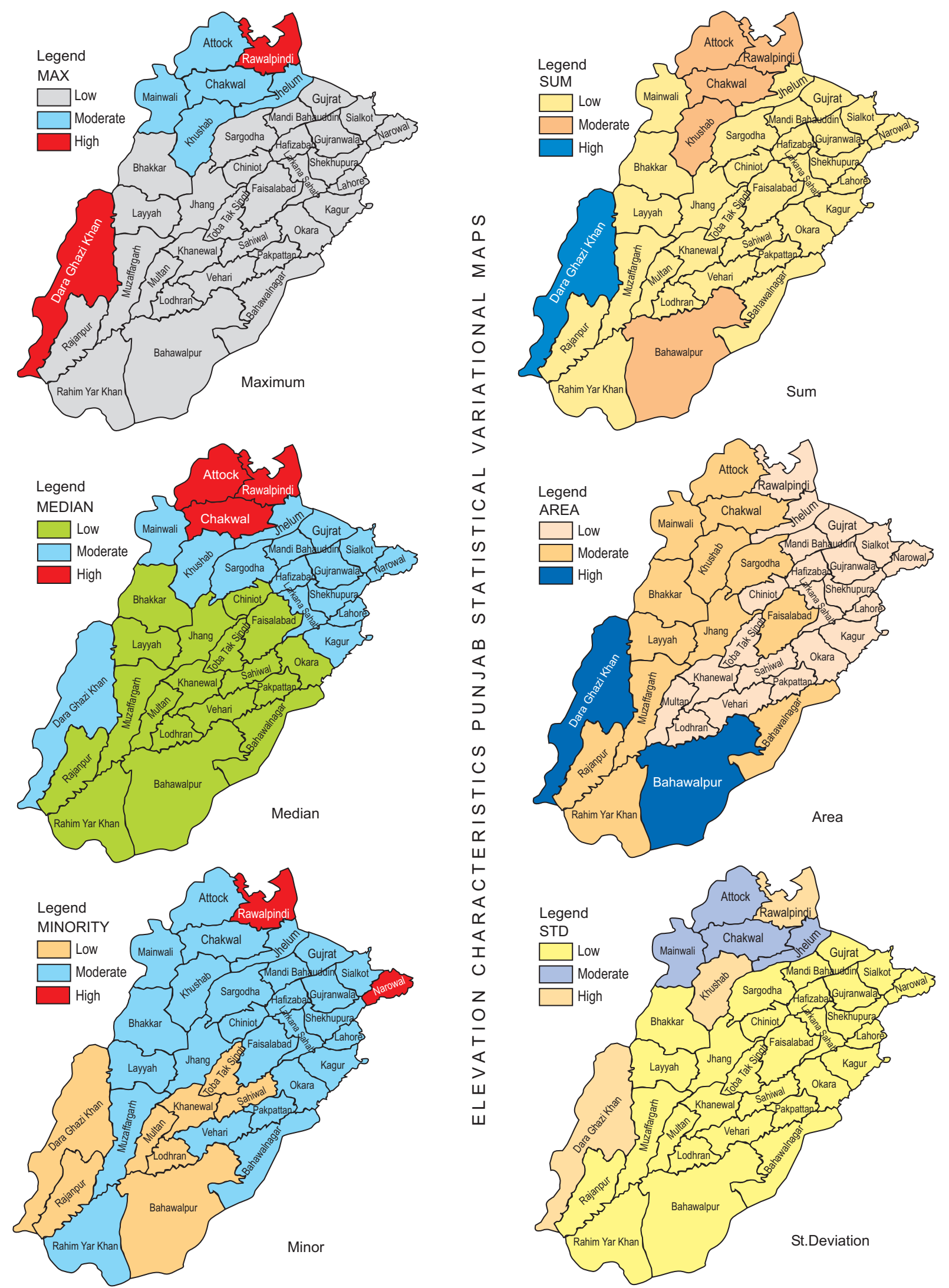

Fig. 8. Statistical variational map of Punjab district. 


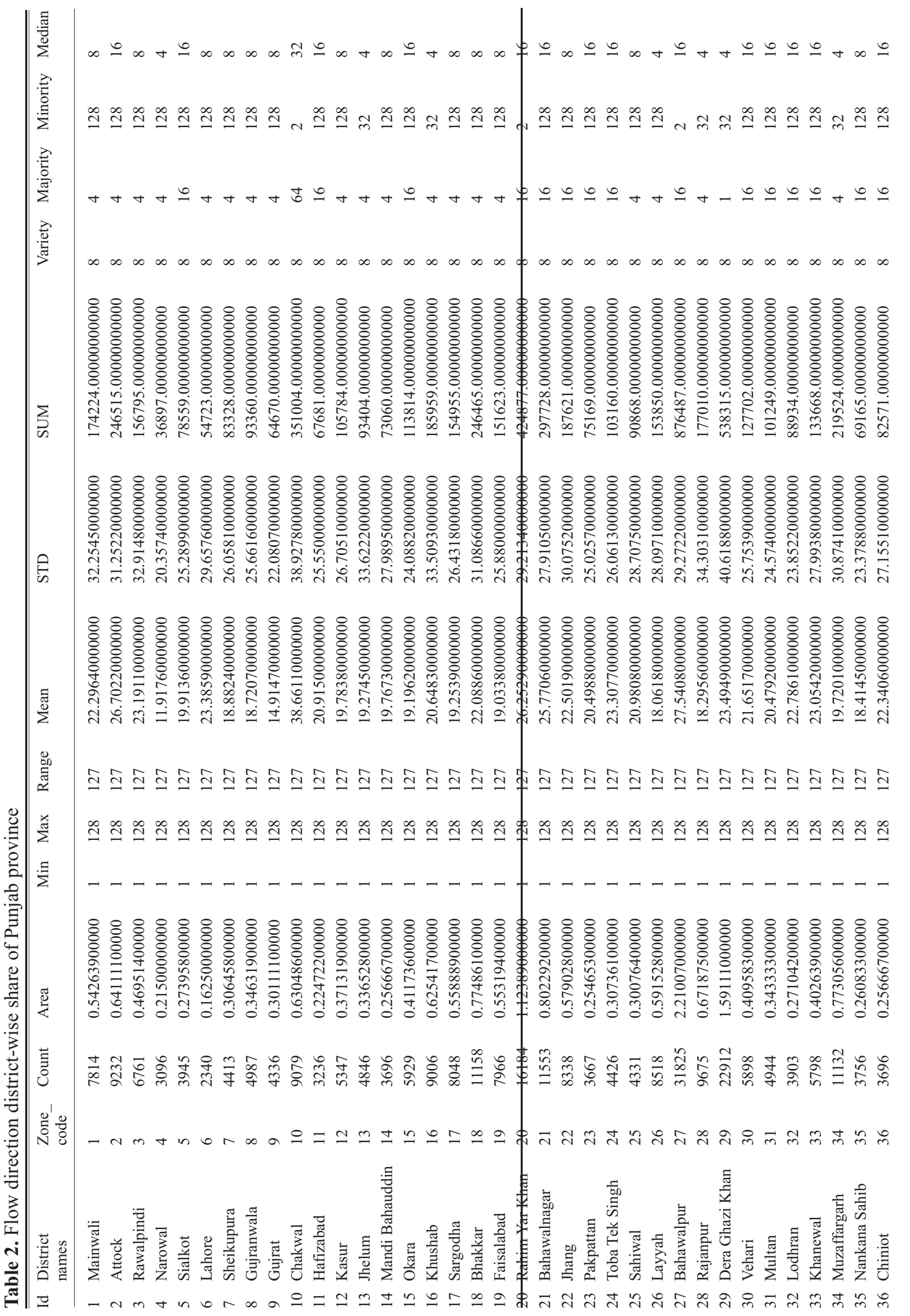




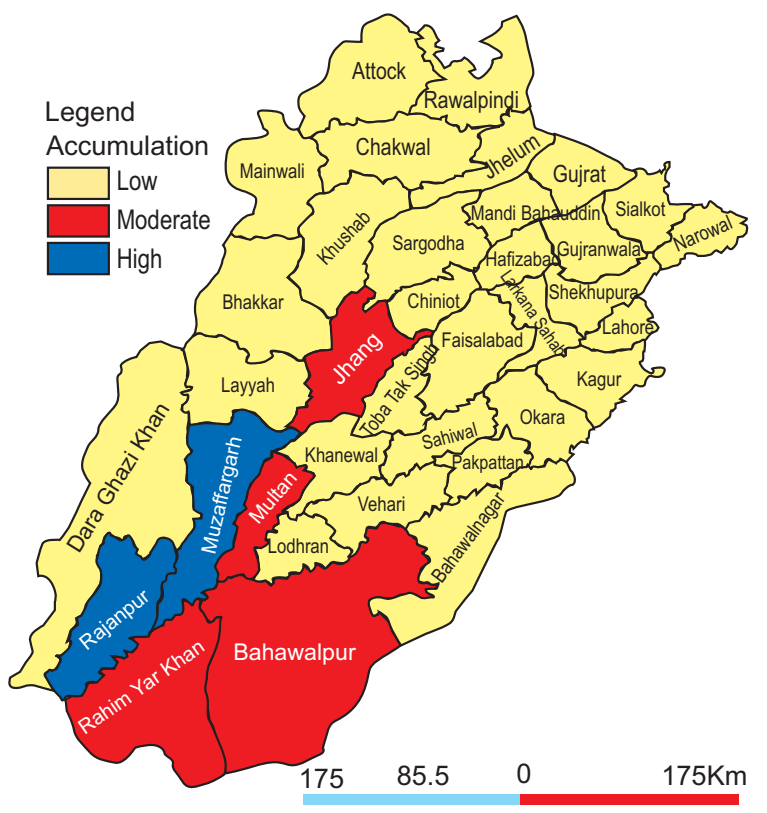

Flow Accumulation Probability

Fig. 9. Flow accumulation - district.

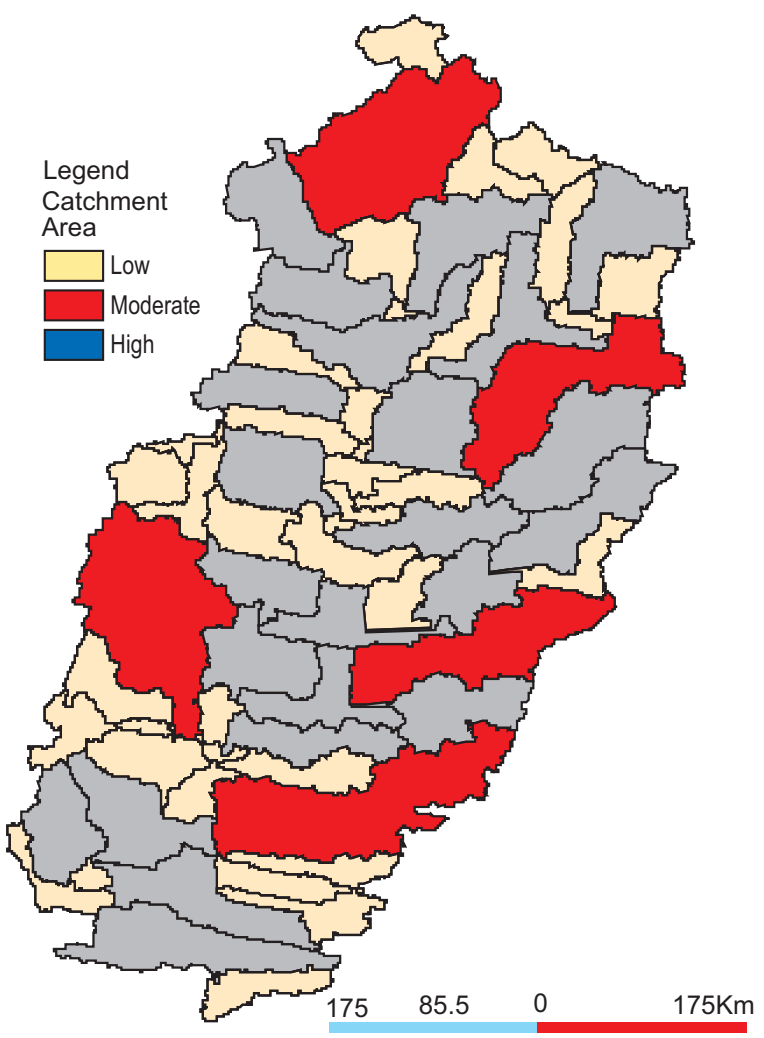

Catchment Area Classes westernmost districts of Punjab Bhawalpur and Dera Ghazi Khan is having a high catchment density encircling the 15 and 10 catchment polygon count respectively, (Table 3). While the Chakwal, Layyah, Kushab, Sargodha, Jhang, Bhakkar, Faisalabad districts are in moderate category and the remaining districts like Khanewal, Lodhran, Vehari, Pakpatan, Sahiwal, Okara, Toba tek Singh, Kasur, Nankana sahib, Hfizabad,
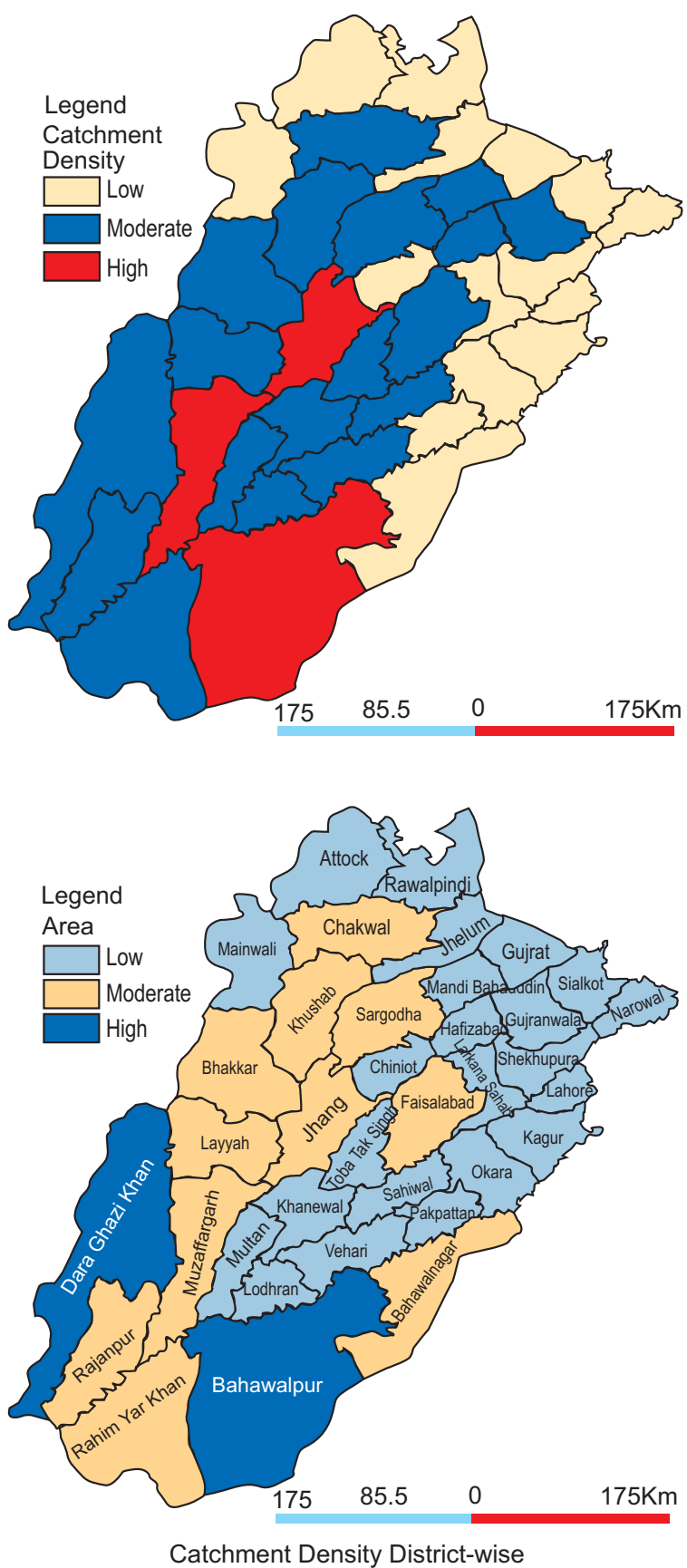

Fig. 11. Catchment density - district wise.

Fig. 10. Catchment zones. 
Table 3. Catchment Density and Counts

\begin{tabular}{|c|c|c|c|c|}
\hline Id & Name & Province & Cat_Dis_Ar & Cat_Dis_Co \\
\hline 1 & Mainwali & Punjab & 4778780687 & 3 \\
\hline 2 & Attock & Punjab & 3901439487 & 2 \\
\hline 3 & Rawalpindi & Punjab & 2089692611 & 4 \\
\hline 4 & Narowal & Punjab & 0 & 0 \\
\hline 5 & Sialkot & Punjab & 1589225322 & 2 \\
\hline 6 & Lahore & Punjab & 823028890 & 2 \\
\hline 7 & Sheikupura & Punjab & 2603449112 & 4 \\
\hline 8 & Gujranwala & Punjab & 3305395712 & 6 \\
\hline 9 & Gujrat & Punjab & 3006925737 & 4 \\
\hline 10 & Chakwal & Punjab & 6547563755 & 6 \\
\hline 11 & Hafizabad & Punjab & 2362742972 & 6 \\
\hline 12 & Kasur & Punjab & 2717603804 & 3 \\
\hline 13 & Jhelum & Punjab & 3270190343 & 3 \\
\hline 14 & Mandi Bahauddin & Punjab & 2687784067 & 6 \\
\hline 15 & Okara & Punjab & 4070488303 & 5 \\
\hline 16 & Khushab & Punjab & 6557651414 & 9 \\
\hline 17 & Sargodha & Punjab & 5865371647 & 8 \\
\hline 18 & Bhakkar & Punjab & 6797850003 & 8 \\
\hline 19 & Faisalabad & Punjab & 5858808069 & 6 \\
\hline 20 & Rahim Yar Khan & Punjab & 9913077272 & 10 \\
\hline 21 & Bahawalnagar & Punjab & 7829835559 & 4 \\
\hline 22 & Jhang & Punjab & 6119635818 & 14 \\
\hline 23 & Pakpattan & Punjab & 2721978337 & 4 \\
\hline 24 & Toba Tek Singh & Punjab & 3270587698 & 6 \\
\hline 25 & Sahiwal & Punjab & 3205987304 & 7 \\
\hline 26 & Layyah & Punjab & 6129910485 & 8 \\
\hline 27 & Bahawalpur & Punjab & 22758088164 & 15 \\
\hline 28 & Rajanpur & Punjab & 7239180864 & 10 \\
\hline 29 & Dera Ghazi Khan & Punjab & 15165159536 & 10 \\
\hline 30 & Vehari & Punjab & 4382527642 & 7 \\
\hline 31 & Multan & Punjab & 3671622565 & 8 \\
\hline 32 & Lodhran & Punjab & 2915417722 & 6 \\
\hline 33 & Khanewal & Punjab & 4295591785 & 8 \\
\hline 34 & Muzaffargarh & Punjab & 8266040301 & 15 \\
\hline 35 & Nankana Sahib & Punjab & 2767148666 & 3 \\
\hline 36 & Chiniot & Punjab & 2703181366 & 5 \\
\hline
\end{tabular}

Chiniot, Gujranwala, Mandi bhauddin, Jehlum districts etc are in the low catchment density zone.

\section{Conclusion}

It is concluded that, GIS and Remote Sensing play a vital function in calculating and delineating the watershed, calculation of flow statistics, flow paths, stream network, drainage dynamics etc. It holds enough potential to address different hydrological associated issues. Development of watershed model using DEM and Hydrological tools provided in ArcGIS leading towards the accurate hydrological modeling as compared to the manual techniques or it is obvious that digital methods overcome the flaws of manual representation therefore, globally catchment geometric properties are preferably extracted by digital means. It is mandatory for the developing countries especially agro-based economic countries, like Pakistan to adopt such technological advancement for the better management of water and other resources. This study helps in understanding the usefulness of DEM data for hydrological studies and leads to derive a better technique of water management in Punjab province of Pakistan. Further calibration, adjustment and validation would give more precise results and enhance the possibilities for watershed and drainage pattern assessment. In the time to come, it will be indispensable to carry on this subject area to receive the optimal solutions for watershed management in the field region.

\section{References}

Jenson, S.K., Domingue, J.O. 1988. Extracting topographic structure from digital elevation data for geographic information system analysis. Photogrammetric Engineering and Remote Sensing, 54: 1593-1600.

Mark, 1984. Link length distributions in drainage networks with lakes. Water Resources Research, 20: 457-462.

Martz, L.W., Garbrecht, J. 1992. Numerical definition of drainage network and sub-catchment areas from digital elevation models. Computers \& Geosciences, 18: $747-761$.

Moore, I.D., Grayson, R.B., Ladson, A.R. 1991. Digital terrain modelling: A review of hydrological, geomorphological and biological applications. Hydrological Processes, 5: 3-30.

Tarboton, D.G., Bras, R.L., Rodriguez-Iturbe, I. 1991. On the extraction of channel networks from digital elevation data. Hydrological Processes, 5: 81-100. 